\title{
Locally Advanced Cervical Carcinoma
}

National Cancer Institute

\section{Source}

National Cancer Institute. Locally Advanced Cervical Carcinoma. NCI Thesaurus. Code C156295.

A cervical carcinoma that has spread from its original site of growth to nearby tissues or lymph nodes. 